\title{
Is it metastatic melanoma or is it sarcoidosis? Non- caseating granulomas due to pembrolizumab
}

\author{
Michael Chahin (1) , Anthony Stack, ${ }^{1}$ Anwer Siddiqi, ${ }^{2}$ Marwan Shaikh ${ }^{3}$
}

${ }^{1}$ Internal Medicine, University of Florida College of Medicine - Jacksonville, Jacksonville, Florida, USA

${ }^{2}$ Pathology and Laboratory Medicine, University of Florida College of Medicine - Jacksonville, Jacksonville, Florida, USA

${ }^{3}$ Hematology/Oncology, Mayo Clinic Hospital, Jacksonville, Florida, USA

\section{Correspondence to} Dr Michael Chahin; michael.chahin@jax.ufl.edu

Accepted 2 December 2020

\section{DESCRIPTION}

A 61-year-old man with a history of multiple basal cell carcinoma presented with a nodular, pigmented lesion on the left side of his scalp. A shave biopsy revealed malignant melanoma. The patient then underwent wide local excision of the melanoma, with left occipital sentinel lymph node negative for tumour involvement. However, 2 months later, he noticed a swelling on the left side of his neck. A subsequent left neck excisional biopsy revealed one of six lymph nodes positive for melanoma. A follow-up positron emission tomography (PET) scan did not reveal distant metastasis. Final staging was IIB, pT3a, pN1b and cM0.

This patient received adjuvant intensitymodulated radiotherapy, followed by intravenous pembrolizumab $200 \mathrm{mg}$ every 21 days with a planned total duration of 1 year. He tolerated six cycles of pembrolizumab with only mild fatigue and cough. Follow-up PET/CT scan after these cycles revealed possible progression of his disease. There was fluorodeoxyglucose-avid adenopathy throughout the mediastinum, bilateral infraclavicular and supraclavicular nodes, and likely periaortic and porta hepatis nodes (figure 1).

Given the extent of his, possible, recurrent disease, he did not receive further radiotherapy. He was

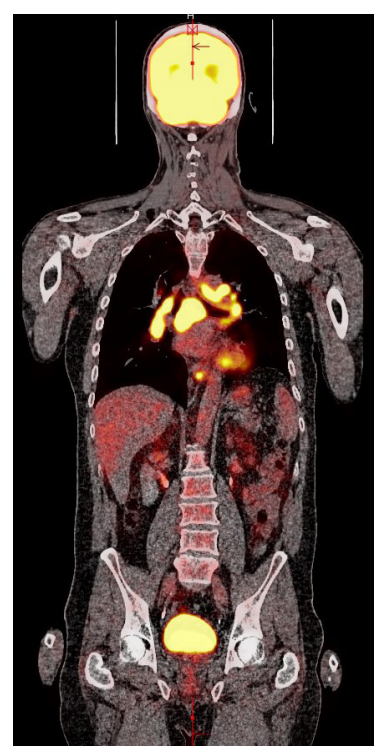

(C) BMJ Publishing Group Limited 2020. No commercial re-use. See rights and permissions. Published by BMJ.

To cite: Chahin M, Stack A, Siddiqi $A$, et al. BMJ Case Rep 2020;13:e240701. doi:10.1136/bcr-2020240701

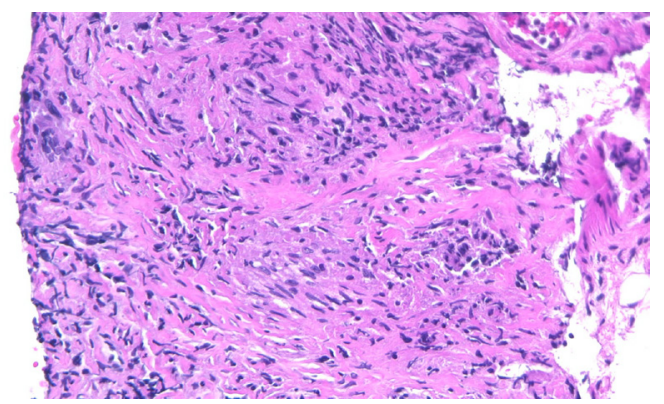

Figure 2 Photomicrograph illustrating non-necrotising granulomatous inflammation with numerous epithelioid histiocytes and a few lymphocytes in the background (H\&E, 10x).

switched to intravenous ipilimumab $3 \mathrm{mg} / \mathrm{kg}$ every 21 days. He tolerated the first treatment well with minor stomach upset. Prior to his second cycle of ipilimumab, he underwent endobronchial ultrasoundguided biopsy of subcarinal, right paratracheal level IV and right hilar lymph nodes level X. Bronchial washings for cytology was also performed. A biopsy to confirm recurrence was planned prior to starting ipilimumab; however, there was a delay as the interventional radiology team requested a pulmonology evaluation first. Once performed, the subcarinal and paratracheal lymph node biopsies showed nonnecrotising granulomatous inflammation (figure 2).

No melanoma was found in these samples. After cycle two of ipilimumab, he was admitted to the hospital with colitis that improved with high-dose corticosteroids. He was recommended to complete a prednisone taper over a few weeks and then was restarted on pembrolizumab. A follow-up CT chest showed near resolution of the lymph nodes.

Pembrolizumab is a programmed death receptor-1 indicated in melanoma with lymph node involvement following resection, and for unresectable or metastatic disease. This drug (Keytruda), along with other immune checkpoint inhibitors, has been known to cause unique adverse effects, such as thyroiditis, enterocolitis and organising pneumonia. ${ }^{1}$ As in this patient, granulomatous, or sarcoid-like, lesions involving the lungs, and hilar and mediastinal lymph nodes have been reported. ${ }^{2}$ A possible mechanism for this adverse effect is the expansion of CD4+ TH17 cells, which are associated with sarcoidosis. ${ }^{3}$

The management of sarcoidosis-like reactions in these patients generally consists of withholding the drug with or without starting steroids, or continuing therapy with the addition of steroids. In either case, the reactions improve or even resolve in most 
patients. ${ }^{2}$ This case highlights the continued need for awareness of this adverse effect of pembrolizumab. One should consider biopsy of lymph nodes favouring possible metastatic disease in cases like this as it can have a great effect on management.

Learning points

- Non-caseating granulomatous inflammation is an important adverse effect of checkpoint inhibitors such as pembrolizumab.

- A biopsy of an area of possible metastatic disease or recurrence should be considered in patients with lymphadenopathy while on checkpoint inhibitors.

- Sarcoid-like reactions from checkpoint inhibitors have a favourable prognosis regardless of whether the offending drug is stopped with steroids added, or steroids are started and therapy is continued.
Twitter Anwer Siddiqi @anwer.siddiqi@jax.ufl.edu

Contributors MC and AS wrote the manuscript. MS edited the manuscript and was the primary physician caring for the patient. AS provided the histology slide and description.

Funding The authors have not declared a specific grant for this research from any funding agency in the public, commercial or not-for-profit sectors.

Competing interests None declared.

Patient consent for publication Obtained.

Provenance and peer review Not commissioned; externally peer-reviewed.

\section{ORCID iD}

Michael Chahin http://orcid.org/0000-0001-9371-0252

\section{REFERENCES}

1 Bajwa R, Cheema A, Khan T, et al. Adverse effects of immune checkpoint inhibitors (programmed death-1 inhibitors and cytotoxic T-Lymphocyte-Associated protein-4 inhibitors): results of a retrospective study. J Clin Med Res 2019;11:225-36.

2 Tetzlaff MT, Nelson KC, Diab A, et al. Granulomatous/sarcoid-like lesions associated with checkpoint inhibitors: a marker of therapy response in a subset of melanoma patients. J Immunother Cancer 2018;6:14.

3 Gkiozos I, Kopitopoulou A, Kalkanis A, et al. Sarcoidosis-Like reactions induced by checkpoint inhibitors. J Thorac Oncol 2018;13:1076-82.

Copyright 2020 BMJ Publishing Group. All rights reserved. For permission to reuse any of this content visit

https://www.bmj.com/company/products-services/rights-and-licensing/permissions/

BMJ Case Report Fellows may re-use this article for personal use and teaching without any further permission.

Become a Fellow of BMJ Case Reports today and you can:

- Submit as many cases as you like

- Enjoy fast sympathetic peer review and rapid publication of accepted articles

- Access all the published articles

Re-use any of the published material for personal use and teaching without further permission

\section{Customer Service}

If you have any further queries about your subscription, please contact our customer services team on +44 (0) 2071111105 or via email at support@bmj.com.

Visit casereports.bmj.com for more articles like this and to become a Fellow 